\title{
Resting energy expenditure in critically ill patients: Evaluation methods and clinical applications
}

\author{
Ana Cláudia Soncini Sanches ${ }^{1 *}$, Cassiana Regina de Góes ${ }^{2}$, Marina Nogueira Berbel Bufarah² ${ }^{2}$, André luiz Balbi ${ }^{3}$, Daniela Ponce ${ }^{4}$ \\ ${ }^{1}$ MSc in Pathophysiology in Internal Medicine from Faculdade de Medicina de Botucatu, Universidade Estadual Paulista Júlio de Mesquita Filho (FMB-Unesp), Botucatu, SP, Brazil \\ ${ }^{2} \mathrm{PhD}$ in Pathophysiology in Internal Medicine from FMB-Unesp, Botucatu, SP, Brazil \\ ${ }^{3}$ Adjunct Professor of Nephrology, Department of Internal Medicine, FMB-Unesp, Botucatu, SP, Brazil \\ ${ }^{4}$ Habilitation (BR: Livre-docência) in Nephrology, Department of Internal Medicine, FMB-Unesp, Botucatu, SP, Brazi
}

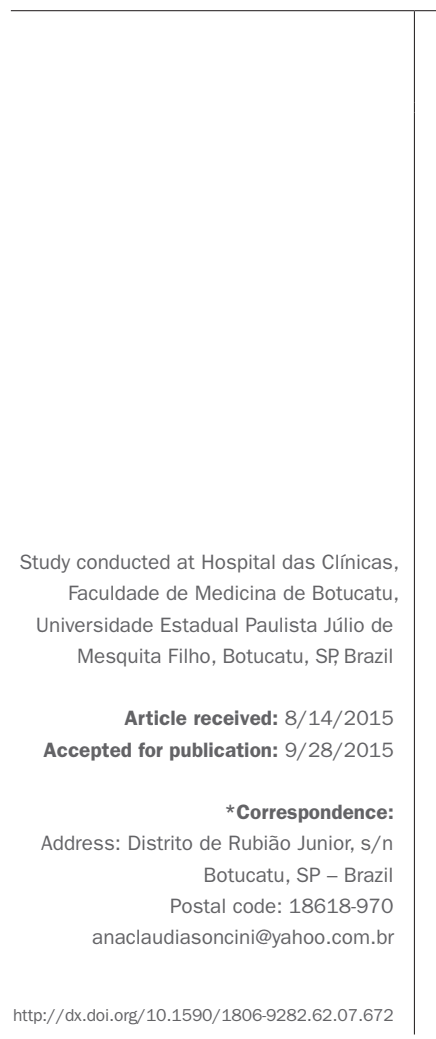

\section{SUMMARY}

Patients on intensive care present systemic, metabolic, and hormonal alterations that may adversely affect their nutritional condition and lead to fast and important depletion of lean mass and malnutrition. Several factors and medical conditions can influence the energy expenditure (EE) of critically ill patients, such as age, gender, surgery, serious infections, medications, ventilation modality, and organ dysfunction. Clinical conditions that can present with EE change include acute kidney injury, a complex disorder commonly seen in critically ill patients with manifestations that can range from minimum elevations in serum creatinine to renal failure requiring dialysis. The nutritional needs of this population are therefore complex, and determining the resting energy expenditure is essential to adjust the nutritional supply and to plan a proper diet, ensuring that energy requirements are met and avoiding complications associated with overfeeding and underfeeding. Several evaluation methods of EE in this population have been described, but all of them have limitations. Such methods include direct calorimetry, doubly labeled water, indirect calorimetry (IC), various predictive equations, and, more recently, the rule of thumb (kcal/ $\mathrm{kg}$ of body weight). Currently, IC is considered the gold standard.

Keywords: energy expenditure, critically ill patient, energy requirement, indirect calorimetry.

\section{IMPORTANCE OF DETERMINING ENERGY EXPENDITURE IN CRITICALLY ILL PATIENTS}

Adequate supply of nutrients is an essential part of the overall treatment of critically ill patients and adjustment of nutritional requirements to the individual needs of patients is a matter crucial to their clinical evolution, because both situations, overfeeding and underfeeding, may contribute to high morbidity and mortality in this population. ${ }^{1,2}$ In such a context, an adequate assessment of energy expenditure (EE) is the basis of effective nutritional planning. ${ }^{3}$

Total energy expenditure (TEE) is defined as the energy required by the body daily, determined by adding the following components: basal energy expenditure (BEE), diet-induced thermogenesis (DIT) and physical activity (PA). ${ }^{4}$

$B E E$ reflects the energy requirements to maintain the intracellular environment and mechanical processes such as respiration and cardiac function, as well as thermoregu- latory mechanisms responsible for regulating the body temperature. ${ }^{5,6} \mathrm{It}$ is considered the main component in TEE, contributing 60 to $75 \%$ of the daily energy requirement for most sedentary individuals and approximately $50 \%$ for the physically active. BEE must be measured in thermoneutral conditions $\left(20^{\circ} \mathrm{C}\right)$ in the absence of recent nutrient administration (12 to 14 hours of fasting), recent physical activity (at least 8 hours of sleep), and psychological stress, while the subject is fully awake, lying in silence, completely relaxed and breathing normally.

The energy corresponding to the thermal effect of food refers to the expenditure caused by digestion, absorption, transport, processing, assimilation and/or storage of nutrients, which varies according to substrate consumed and represents 5 to $15 \%$ of the TEE. ${ }^{4}$ It is considered that in a usual mixed diet (with lipids, carbohydrates, and proteins), the thermal effect of food is approximately 5 to $7 \%$ of its energy content. 
Finally, the EE for the completion of the external mechanical work is defined as the effect of physical activity, representing 15 to $30 \%$ of the daily TEE. The variation takes into account intensity and duration of exertion. ${ }^{6}$

As described, the measurement of BEE requires the individual to remain in specific conditions, which often makes it difficult to obtain a baseline. Thus, usually, the resting energy expenditure (REE), which is very close to the $\mathrm{BEE}$, is measured with the subject at rest. REE may be 3 to $10 \%$ greater than BEE due to DIT and the influence of the latest PA. ${ }^{4,7}$

Factors such as age, gender, body composition, hormones, and genetics can exert influence on the REE in both healthy individuals and those who are ill. Body composition is believed to be one of the major determinants of metabolic rate, so that individuals with predominantly lean body mass have higher $\mathrm{EE}$, while fat mass is metabolically less active. ${ }^{8}$

Certain medical conditions can also change the REE. The use of nutritional support and certain medications can raise up to $10 \%$ this expenditure. Clinical and surgical diseases usually increase REE as part of the metabolic response to stress. Postoperatively to elective surgeries, REE can increase from 5 to $20 \%$. Multiple fractures, extensive abdominal injury, central nervous system trauma, and severe infections may raise the REE 50 to $60 \%{ }^{9}$

Faisy et al. ${ }^{10}$ found that in patients on mechanical ventilation, weight, height, body temperature, type of mechanical ventilation, and type of medication received influenced the REE. Fever is another important factor that changes the REE, so that each $1^{\circ} \mathrm{C}$ increase in temperature raises the REE by $11 \%{ }^{8}$ Conversely, different equipment and methods of mechanical ventilation, as well as medications such as sedatives, painkillers, and muscle relaxants seem to reduce the metabolic and systemic stress of patients, with consequent reduction in REE. ${ }^{10}$

Clinical conditions that can present with REE change include acute kidney injury (AKI), a complex disorder commonly seen in critically ill patients with manifestations that can range from minimum elevations in serum creatinine to renal failure requiring dialysis. ${ }^{11}$ Its incidence in the intensive care unit (ICU) is 20 to $40 \%{ }^{12}$ and is associated with high mortality rates, which may reach $60 \%$ in those requiring dialysis. ${ }^{13}$ This critical population has complex nutritional needs and as part of the metabolic response to acute disease, sepsis or trauma, the BEE can be altered, leading to intense catabolism accompanied by hyperglycemia combined with insulin resistance, progressive loss of lean body mass, and severe lipolysis. ${ }^{14}$ Such metabolic changes associated with lack of adequate nu- tritional support can lead to rapid and significant depletion of lean body mass and malnutrition, ${ }^{15,16}$ as well as prolonged use of mechanical ventilation, hyperglycemia, and liver dysfunction in cases of overfeeding. ${ }^{17,18}$

Thus, many of the severe patients have a characteristic hypermetabolism, which aims to acutely provide energy and substrate for the immune system and coagulation pathways to fight pathogens, stop bleeding, and repair damaged tissues. Such a response is beneficial; however, it coincides with great body exhaustion including protein degradation and early onset of malnutrition, in which case the patient becomes more susceptible to infections and thus to longer hospital stays, higher hospital costs, and increased mortality. ${ }^{19,20}$ In this scenario, underfeeding associated with increased energy demand could adversely affect the prognosis of patients.

Dvir et al., ${ }^{21}$ in an observational study of 50 ICU patients, showed an association between greater energy deficit and adult respiratory distress syndrome $(\mathrm{p}=0.0003)$, sepsis $(\mathrm{p}=0.0035)$, renal failure $(\mathrm{p}=0.0001)$, pressure ulcers $(\mathrm{p}=0.013)$, need for surgery $(\mathrm{p}=0.023)$, and total rate of complications $(\mathrm{p}=0.0001)$, but no association with duration of mechanical ventilation, ICU stay or hospital stay and mortality. ${ }^{21} \mathrm{Sim}-$ ilar results were observed by Villet et al., ${ }^{1}$ who also discovered a correlation between negative energy balance and clinical complications, especially infection $(\mathrm{p}<0.001)$.

In a study of a small group of 38 critically ill patients on prolonged mechanical ventilation, the authors found that a deficit of approximately $1,200 \mathrm{kcal} /$ day was associated with independent risk of death in ICU (OR 6.12, 95CI 1.33-28.2; $\mathrm{p}=0.01) .{ }^{22}$ In another study, Alberda et al. ${ }^{23}$ noted that an increase of $1,000 \mathrm{kcal} /$ day was associated with overall reduction in mortality of patients in intensive care (OR 0.76, 95CI 0.61-0.95; $\mathrm{p}=0.014$ ).

On the other hand, overfeeding also has negative effects, such as respiratory and metabolic disorders, including hypercapnia, need for prolonged mechanical ventilation, hyperglycemia, hepatic steatosis, azotemia, hypertonic dehydration, metabolic acidosis, hypertriglyceridemia, and refeeding syndrome, as well as known deleterious effects related to infection and patient outcomes. ${ }^{5,24}$ In a multicenter study conducted in 40 Spanish ICUs and that included 725 patients, Grau et al. showed that overfeeding (>27 kcal/kg) was one of the determinants of abnormal liver function..$^{25}$ According to the study of Dissanaike et al., ${ }^{26}$ increased parenteral caloric intake was a risk factor for infection of the bloodstream; this association was independent of the occurrence of hyperglycemia.

According to the authors, critical patients have a number of systemic, metabolic, and hormonal changes 
that can adversely affect their nutritional status. This makes the determination of REE essential for adjusting the nutritional supply and thus allows the planning of an adequate diet to ensure that energy needs are met and to avoid the complications associated with overfeeding or underfeeding. ${ }^{27}$

\section{MetHODS FOR DETERMINATION OF ENERGY EXPENDITURE}

The calculation of energy needs is an integral part of nutritional care of critically ill patients. Determining the exact $\mathrm{EE}$ is one of the great difficulties in clinical practice, as acute disease and its treatment affect metabolism, increasing or decreasing the patient's EE. ${ }^{28}$

Several evaluation methods of EE in this population have been described, but all of them have limitations. ${ }^{29}$ They include direct calorimetry (DC), doubly labeled water (DLW), indirect calorimetry (IC), several predictive equations, and, more recently, the rule of thumb (kcal/ $\mathrm{kg}$ of body weight).

The use of a rule of thumb based on guidelines issued by medical societies such as the American Society of Enteral and Parenteral Nutrition (ASPEN), the European Society for Clinical Nutrition and Metabolism (ESPEN) and the Canadian Critical Care Clinical Practice Guidelines Committee (CCPG) is a common practice to estimate REE, and although there is a consensus among these entities, a few discrepancies are found. ${ }^{30}$ US guidelines recommend 25 to $30 \mathrm{kcal} / \mathrm{kg}$ of current body weight in adults, and in the case of critically-ill obese patients, they recommend 11 to $14 \mathrm{kcal} / \mathrm{kg}$ of current body weight or 22 to $25 \mathrm{kcal} / \mathrm{kg}$ of ideal body weight (IW). ${ }^{31}$

DC is a method based on the use of a thermally insulated chamber to directly measure the heat generated by the body. It is considered highly precise ( 1 to $2 \%$ error), but with little viable applicability ${ }^{32}$ as it requires a very sophisticated camera and permanence of the subject in the chamber for a period equal to or greater than 24 hours. ${ }^{33}$ Thus, studies point to the efficacy and use of the indirect method. ${ }^{34} \mathrm{~A}$ study comparing the EE of three patients during 40 days, obtained through direct and IC, showed difference of only $0.22 \%$ between the two methods $(2,723 \mathrm{kcal} / 24 \mathrm{~h} v$ s. $2,717 \mathrm{kcal} / 24 \mathrm{~h})$. Other studies in animal and human models have shown good correlation between DC and IC, with differences below 1\%. ${ }^{35}$

The method of DLW consists in using water doubly labeled with ${ }^{2} \mathrm{H}$ and ${ }^{18} \mathrm{O}$, which must be ingested by the subject whose disappearance rate of body fluid (water) is then monitored for 7 to 21 days, approximately. The difference between the rates of disappearance of two isotopes, corrected for body water pool, enables to estimate the carbon dioxide $\left(\mathrm{CO}_{2}\right)$ production rate that, based on IC equations, reveals the TEE of the individual. ${ }^{36}$ The accuracy of the method is 97 to $99 \%$ compared to IC. ${ }^{37}$ In studies with adults in energy balance, in which the results from the DLW were compared with those obtained by IC, Coward et al..$^{38}$ obtained error at $1.9 \pm 2 \%$ in the estimated production of $\mathrm{CO}_{2}$, while Schoeller \& Webb ${ }^{39}$ obtained error at $1.5 \pm 7.6 \%$. However, DLW is most commonly used to measure the TEE in individuals not confined to a calorimetry room, in special conditions such as lactating, in sports activities, validation of assessment instruments of physical activity and/or EE, and validation of methods to assess dietary intake. It is not commonly used in hospitals. ${ }^{40}$

IC is considered the gold standard for measuring REE in critically ill patients, ${ }^{41,42}$ and measurement is based on gas exchange, with energy production from the consumption of oxygen $\left(\mathrm{O}_{2}\right)$ and production of $\mathrm{CO}_{2}$. It is estimated that approximately $80 \%$ of EE is due to $\mathrm{O}_{2}$ consumption, while the remaining $20 \%$ are attributed to EE due to $\mathrm{CO}_{2}$ production. ${ }^{43,44}$ It is considered a safe, non-invasive, and precise method, with error less than $1 \%$, with high reproducibility and almost free of complications. ${ }^{4}$

The calorimeter is a simple device, portable, a type of "open circuit" that supports the patient while breathing air either connected or not to a respirator. In both situations, the samples of inspired/expired gas are collected by the device for analysis of the $\mathrm{CO}_{2}$ fraction in expired air, $\mathrm{O}_{2}$ fraction in the inhaled and exhaled air, and inspiratory and expiratory flows. Through analysis of these parameters, oxygen consumption $\left(\mathrm{VO}_{2}\right)$ and carbon dioxide production $\left(\mathrm{VCO}_{2}\right)$ are measured, and REE is obtained by transforming these values using the classical Weir equation: $:^{45-47}$

Energy expenditure $(\mathrm{kcal})=\left[3.941\left(\mathrm{VO}_{2}\right)+1.106\left(\mathrm{VCO}_{2}\right)\right] \times 1440$

Respiratory volumes are measured in $\mathrm{L} / \mathrm{min}$, and factor 1440 expresses the number of minutes in 24 hours.

A second important result obtained from the IC is the respiratory quotient (RQ), defined as the ratio between $\mathrm{VCO}_{2}$ emitted by body tissues and the $\mathrm{VO}_{2}$ absorbed by them $\left(\mathrm{RQ}=\mathrm{VCO}_{2} / \mathrm{VO}_{2}\right)$. RQ are in a very narrow range in humans $(0.67-1.2)^{48}$ and, thus, values outside of this range suggest the presence of technical errors in measurement.

Some mechanical, environmental, and metabolic aspects must be observed to ensure test accuracy. The environment should be quiet, with dim lighting and temperature around $20^{\circ} \mathrm{C}$, with the patient at rest for at least 30 minutes and fasting for 2 to 3 hours. ${ }^{49}$ In patients who 
are receiving nutritional therapy or intravenous glucose solution, the rate of infusion of solutions should be kept constant. ${ }^{50}$ The $\mathrm{O}_{2}$ and $\mathrm{CO}_{2}$ analyzers must be calibrated with a known concentration of gas before each determination and periodically validated according to the manufacturer's specifications. ${ }^{6}$ For individuals on mechanical ventilation, modifying the system to a regime of constant moisture content of the air and oxygen is not recommended for 90 minutes before measuring. ${ }^{6}$ The inspired gas sample collection tube should be as close as possible to the patient, making sure that there are no leaks in the connections of the breathing circuit. The endotracheal tube should also be perfectly adapted and without leaks. ${ }^{50}$ Furthermore, the fraction of inspired oxygen $\left(\mathrm{FiO}_{2}\right)$ must be stable and below $60 \%$, since greater values increase the likelihood of errors in the results obtained. ${ }^{50}$

The calorimetric test duration is based on reaching the Steady State, considered a metabolic balance period where changes in $\mathrm{VCO}_{2}$ and $\mathrm{VO}_{2}$ are $<10 \%$ for 5 consecutive minutes or the average of the coefficient of variation (CV) for these two values is less than $5 \%{ }^{7,51-56}$ Calorimeters typically require a 30 minute test period to reach Steady State, the first 5 minutes of the test being discarded. ${ }^{7,51}$ Metabolic balance must be achieved in order to reduce errors and ensure the validity of the test..$^{54,57}$

In Brazil, it is known that the application of this method to evaluate patients in hospitals is not a routine, since the equipment is expensive and requires specialized labor to be handled properly. ${ }^{58}$

The predictive equations comprise a commonly used alternative method to determine the energy needs according to estimates of EE due to zero cost and ease of application. There are about 190 equations published in the literature using variables such as weight, height, age, gender, and body surface. ${ }^{29}$ The most used are the Harris-Benedict equation (1919), ${ }^{48}$ the Mifflin-St Jeor equation (1990), ${ }^{59}$ the Ireton-Jones equation (1992), ${ }^{60}$ and the Penn State equation (2003), ${ }^{61}$ described in Table 1.

The accuracy of the method in hospitalized patients has been questioned, particularly in critically ill, malnourished and elderly patients. ${ }^{62,63}$ In addition, any occasional error in REE obtained using predictive equations can be further increased when activity and injury factors are applied to empirically adjust the needs altered in patients with acute disease. ${ }^{64}$

Boullata et al. ${ }^{65}$ evaluated the efficacy of seven predictive equations, including the Harris-Benedict, the Mifflin-St Jeor, the Ireton-Jones, and the Penn State equations, to predict REE in 365 hospitalized patients, including critically ill and obese individuals. None of the equa-
TABLE 1 Description of predictive equations.

\begin{tabular}{ll}
$\begin{array}{ll}\text { Name of } \\
\text { equation }\end{array}$ & Calculation of REE \\
\hline Harris-Benedict & Male: $66.5+\left(13.8 \times \mathrm{P}^{\mathrm{a}}\right)+\left(5 \times \mathrm{A}^{\mathrm{b}}\right)-\left(6.8 \times \mathrm{I}^{\mathrm{c}}\right)$ \\
\cline { 2 - 2 } & Female: $655+\left(9.6 \times \mathrm{P}^{\mathrm{a}}\right)+\left(1.8 \times \mathrm{A}^{\mathrm{b}}\right)-\left(4.7 \times \mathrm{I}^{\mathrm{c}}\right)$ \\
\hline Mifflin-St Jeor & Male: $5+\left(10 \times \mathrm{P}^{\mathrm{a}}\right)+\left(6.25 \times \mathrm{A}^{\mathrm{b}}\right)-\left(5 \times \mathrm{I}^{\mathrm{c}}\right)$ \\
\cline { 2 - 2 } & Female: $-161+\left(10 \times \mathrm{P}^{\mathrm{a}}\right)+\left(6.25 \times \mathrm{A}^{\mathrm{b}}\right)-\left(5 \times \mathrm{I}^{\mathrm{c}}\right)$ \\
\hline Ireton-Jones & $1.925+\left(5 \times \mathrm{P}^{\mathrm{a}}\right)-\left(10 \times \mathrm{I}^{\mathrm{c}}\right)+\left(281 \times \mathrm{G}^{\mathrm{d}}\right)+\left(292 \times \mathrm{Tr}^{\mathrm{e}}\right)$ \\
\hline Penn State & $+\left(851 \times \mathrm{Q}^{\mathrm{f}}\right)$ \\
\hline
\end{tabular}

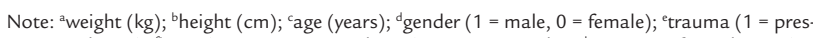
ent, $0=$ absent); fburn ( 1 = present, $0=$ absent $)$; ${ }^{g}$ Harris-Benedict; ${ }^{\text {h}}$ minutes of ventilation $(\mathrm{L}$ / $\mathrm{min})$; ' $m$ maximum temperature $\left({ }^{\circ} \mathrm{C}\right)$; REE: resting energy expenditure.

tions precisely predicted the REE, regardless of age, gender, race, body mass index, and ventilatory status. Even using the global equation of Harris-Benedict, $39 \%$ of patients had imprecise REE results, with $400 \mathrm{kcal}$ error above or below the REE measured by IC. In obese individuals, prediction based on the Harris-Benedict equation was more precise than any other equation in $62 \%$ of the sample. However, there was still a mean error of $47 \mathrm{kcal}$, with an agreement range between $+534 \mathrm{kcal}$ and $-440 \mathrm{kcal}^{65}$

In a prospective observational study involving 40 adult patients admitted to the ICU, the authors observed that the REE estimated using the Ireton-Jones formula overestimated REE measured by IC, obtaining a mean difference between the IC and the equation of $-353.83 \mathrm{kcal}$, ranging from - $904.77 \mathrm{kcal}$ to $197.11 \mathrm{kcal}$, with a significant difference between measured and estimated EE for the same individual $(\mathrm{p}<0.004) .{ }^{58}$

Although the inaccuracy of predictive equations is shown in numerous studies, the unavailability of a calorimeter in many services causes such equation to be routinely used to assist in the estimation of energy needs, based on publications that demonstrate greater concordance between the estimated EE and that measured by IC.

Faisy et al. ${ }^{10}$ evaluated the EE measured by IC and compared it to the value estimated by the Harris-Benedict equation. They noted that although EE on IC was $25 \%$ greater, the difference was not statistically significant when the injury factor was applied for adjustment. In another study conducted in the previous year, Cheng et al. ${ }^{66}$ analyzed the accuracy of five predictive equations to estimate the EE of 46 patients on mechanical ventilation, including the Harris-Benedict and Kleiber and Liu equations, noting that EE can be estimated in most critically ill patients by these equations, provided that an injury factor is used. 
The predictive equation of Harris-Benedict is one of the oldest and most used to date; however, it is not recommended in critically ill patients. ${ }^{67,68}$ The Penn State University equation is the most exact and precise indicator of REE in the critically ill patients, and should be used when IC is not feasible, combined or not with the rule of thumb in order to improve precision. ${ }^{42,61,69,70}$

IC is the best technique to ensure exact determination of $\mathrm{EE}$ and consequently the ideal nutritional intake, and thus should be use whenever possible in critically ill patients.

\section{ENERGY EXPENDITURE IN ACUTE KIDNEY INJURY}

Observational studies show a strong association between cumulative energy deficits and worse renal outcomes and survival, as well as correlation between malnutrition and increased morbidity and mortality in intensive care patients affected by AKI. ${ }^{21,71}$ Thus, the adequate supply of nutritional requirements by determining the actual EE in this population is relevant.

When AKI is monofactorial and uncomplicated, REE does not seem to be changed, although the kidney is responsible for about $10 \%$ of the REE. ${ }^{72}$ Studies have shown that the metabolism in non-complicated AKI, measured using calorimetry, seldom exceeds 1.3 times the BEE obtained by the Harris-Benedict equation. . $^{10,72,73}$

As AKI affects up to a third of patients admitted to the ICU, it is rarely monofactorial and non-complicated. Most commonly, it is part of a more complex disease such as sepsis, multiple organ failure, shock, trauma or high-risk surgery, with resulting hypermetabolism and hypercatabolism. ${ }^{74}$ There is evidence that severe sepsis and septic shock are the most important causes of AKI in critically ill patients, corresponding to $50 \%$ or more of these cases in ICU. The occurrence of AKI in this critical population, in addition to the significant impact on morbidity and increased length of stay and hospital costs, is an independent risk factor for mortality in affected patients. ${ }^{75}$

As important as the AKI in the prognosis of these patients are comorbidities, previous nutritional status, and complications such as infection, inflammation, and ventilatory support, which alter the EE of these patients. ${ }^{72,76}$

Schneeweiss et al. ${ }^{77}$ studied energy metabolism by IC in 86 patients with various forms of renal failure and in 24 control subjects. The groups were: AKI with sepsis $(\mathrm{n}=18)$, AKI without sepsis $(\mathrm{n}=11)$, chronic kidney disease (CKD) in pre-dialysis phase ( $\mathrm{n}=17$ ), CKD on hemodialysis $(n=25)$, and patients with severe untreated azotemia $(n=15)$. They noted that the REE was increased only in patients with AKI associated with sepsis and was not correlated with body temperature $(\mathrm{r}=0.359)$. Patients with septic AKI showed a 33\% increase in REE, while AKI not associated with sepsis, dialysis, and uremia did not change the REE. However, the study did not evaluate the influence of dialysis in REE of patients with AKI, or sepsis in the absence of AKI.

Some studies assessed if the uremia and dialysis affect $\mathrm{EE}$ in CKD patients, with conflicting results. The first study, conducted over 20 years ago, showed that REE in CKD patients either undergoing dialysis or not was similar to that of healthy individuals. ${ }^{77,78}$ Ikizler et al., ${ }^{79}$ in 1996, reported that patients on hemodialysis had significantly higher REE than the healthy controls matched for gender, age, and body mass index (BMI). More recent studies with larger numbers of clinically stable patients with CKD, matched by gender and age with healthy controls, showed different results. Patients with CKD on conservative treatment were hypometabolic, i.e. with REE lower than the control group, ${ }^{80,81}$ while dialysis patients treated by hemodialysis and peritoneal dialysis showed REE similar to the controls. ${ }^{82,83}$ When evaluating REE of patients with CKD under catabolic conditions, such as in cases of uncontrolled diabetes mellitus, severe hyperparathyroidism, and inflammation, hypermetabolism has been observed. ${ }^{84,85}$ Avesani et al., ${ }^{84}$ when comparing the REE of diabetic and non-diabetic patients with pre-dialysis CKD, matched for gender, age, and renal function, showed that REE in the diabetic group was $12.5 \%$ (182 kcal/day) higher than that seen in non-diabetics. The same group noted that in patients with pre-dialysis CKD and subclinical inflammation (C-reactive protein levels - CRP $>0.5 \mathrm{mg}$ / dL) REE was significantly higher than in patients with CRP levels $<0.14 \mathrm{mg} / \mathrm{dL}$ even after adjusting for gender, age, and lean body mass. ${ }^{83}$

There are very few studies evaluating REE in patients with AKI and, thus, experts tend to follow protocols used for patients in intensive care to determine the energy demand and other aspects involved in nutritional therapy. ${ }^{86}$ There is a consensus on the recommendation of obtaining the actual EE using IC, if possible, in individuals kept under intensive care, more specifically, people with AKI. ${ }^{31,87}$

The negative impact of overfeeding and underfeeding in the prognosis of these patients and within this context is well-known. Determining the REE and the adequate supply of nutrients is paramount as it contributes to preserve lean body mass and energy reserves, to restore the immune function, to attenuate the inflammatory response and oxidative stress, and to reduce mortality rates in patients with AKI. 


\section{Conclusion}

Determining the energy needs should be an integral part of primary care given to the patient in critical condition, considering the benefits of an adequate supply of nutrients to reduce complications and mortality. Despite its technical and financial limitations, IC proved to be the best method for assessing EE in patients under intensive care. Since there are very few studies on nutritional care of patients with AKI, recommendations for critically ill patients are usually adopted. Thus, the need for new studies that address nutritional aspects and assist in planning appropriate prescription of nutritional therapy for critically ill patients with AKI is evident.

\section{Resumo}

Gasto energético de repouso em pacientes críticos: métodos de avaliação e aplicações clínicas

Os pacientes em cuidados intensivos apresentam alterações sistêmicas, metabólicas e hormonais, que podem afetar adversamente a condição nutricional e levar à rápida e importante depleção da massa magra e desnutrição. Vários fatores e situações clínicas podem exercer influência sobre o gasto energético (GE) de pacientes críticos, como idade, sexo, cirurgias, infecções graves, medicamentos, modalidade ventilatória e disfunção de órgãos. Dentre as condições clínicas que podem cursar com alteração do GE, encontra-se a lesão renal aguda (LRA), distúrbio complexo comumente observado em pacientes críticos, com manifestações que podem variar de mínimas elevações na creatinina sérica até insuficiência renal com necessidade dialítica. Dessa forma, essa população crítica apresenta necessidades nutricionais complexas e a determinação do gasto energético de repouso (GER) torna-se essencial para o ajuste da oferta nutricional e para o planejamento de uma nutrição adequada, assegurando que as necessidades energéticas sejam atingidas e evitando as complicações associadas à hiper ou hipoalimentação. Diversos métodos de avaliação do GE nessa população foram descritos, mas todos apresentam limitações. Dentre eles, destacam-se a calorimetria direta, a água duplamente marcada, a calorimetria indireta (CI), diversas equações preditivas e, mais atualmente, a regra de bolso ( $\mathrm{kcal} / \mathrm{kg}$ de peso). Atualmente, a CI é eleita o método padrão-ouro.

Palavras-chave: gasto energético, paciente crítico, necessidade energética, calorimetria indireta.

\section{References}

1. Villet S, Chioléro RL, Bollmann MD, Revelly JP, Cayeux RN, Delarue J, et al. Negative impact of hypocaloric feeding and energy balance on clinical outcome in ICU patients. Clin Nutr. 2005; 24(4):502-9.

2. Klein CJ, Stanek GS, Wiles III CE. Overfeeding macronutrients to critically ill adults: metabolic complications. J Am Diet Assoc. 1998; 98(7):795-806.

3. De Waele E, Spapen H, Honoré PM, Mattens S, Van Gorp V, Diltoer M, et al. Introducing a new generation indirect calorimeter for estimating energy requirements in adult intensive care unit patients: feasibility, practical considerations, and comparison with a mathematical equation. J Crit Care. 2013; 28(5):884.e1-6.

4. Volp CP, Oliveira FCE, Alves RDM, Esteves EA, Bressan J. Energy expenditure: components and evaluation methods. Nutr Hosp. 2011; 26(3):430-40.

5. Gariballa S, Forster S. Energy expenditure of acutely ill hospitalized patients. Nutr J. 2006; 5:9.

6. Dias ACF, Silva Filho AA, Cômodo ARO, Tomaz BA, Ribas DF, Spolidoro $\mathrm{J}$, et al. Gasto energético avaliado pela calorimetria indireta. Projeto Diretrizes. Associação Médica Brasileira e Conselho Federal de Medicina. 2009.

7. Brandi LS, Bertolini R, Calafà M. Indirect calorimetry in critically ill patients: clinical applications and practical advice. Nutrition. 1997; 13(4):34958.

8. Pi-Sunyer FX. Overnutrition and undernutrition as modifiers of metabolic processes in disease states. Am J Clin Nutr. 2000; 72(2 Suppl):533S-7S.

9. Mahan LK, Escott-Stump S. Energia. In: Krause: alimentos, nutrição e dietoterapia. São Paulo: Roca; 1998. p. 17-29.

10. Faisy C, Guerot E, Diehl JL, Labrousse J, Fagon JY. Assessment of resting energy expenditure in mechanically ventilated patients. Am J Clin Nutr. 2003; 78(2):241-9.

11. Mehta RL, Kellum JA, Shah SV, Molitoris BA, Ronco C, Warnock DG, et al.; Acute Kidney Injury Network. Acute Kidney Injury Network: report of an intitiative to improve outcomes in acute kidney injury. Crit Care. 2007; 11(2):R31.

12. Himmelfarb J, Ikizler TA. Acute kidney injury: changing lexicography, definitions, and epidemiology. Kidney Int. 2007; 71(10):971-6.

13. Uchino S, Kellun JA, Bellomo R, Doig GS, Morimatsu H, Morgera S, et al.; Beginning and Ending Supportive Therapy for the Kidney (BEST Kidney) Investigators. Acute renal failure in critically ill patients: a multinational, multicenter study. JAMA. 2005; 294(7):813-8.

14. Plank LD, Hill GL. Sequential metabolic changes following induction of systemic inflammatory response in patients with severe sepsis or major blunt trauma. World J Surg. 2000; 24(6):630-8.

15. Berger MM, Pichard C. Best timing for energy provision during critical illness. Crit Care. 2012; 16(2):215.

16. Biffl WL, Moore EE, Haenel JB. Nutrition support of the trauma patient. Nutrition. 2002; 18(11-12):960-5.

17. Osborne BJ, Saba AK, Wood SJ, Nyswonger GD, Hansen CW. Clinical comparison of three methods to determine resting energy expenditure. Nutr Clin Pract. 1994; 9(6):241-6.

18. Matamis D, Tsagourias M, Koletsos K, Riggos D, Mavromatidis K, Sombolos $\mathrm{K}$, et al. Influence of continuous haemofiltration-related hypothermia on hemodynamic variables and gas exchange in septic patients. Intensive Care Med. 1994; 20(6):431-6.

19. David MC. Terapia nutricional no paciente grave. Rio de Janeiro: Revinter; 2001.

20. Waitzberg DL, Correia MI. Custos e benefícios da nutrição enteral e parenteral na assistência integral á saúde. Rev Bras Nutr Clin. 1999; 14(4):213-9.

21. Dvir D, Cohen J, Singer P. Computerized energy balance and complications in critically ill patients: an observational study. Clin Nutr .2005; 25(1):37-44.

22. Faisy C, Lerolle N, Dachraoui F, Savard JF, Abboud I, Tadie JM, et al. Impact of energy deficit calculated by a predictive method on outcome in medical patients requiring prolonged acute mechanical ventilation. Br J Nutr. 2009; 101(7):1079-87.

23. Alberda C, Gramlich L, Jones NE, Jeejeebhoy K, Day AG, Dhaliwal R, et al. The relationship between nutritional intake and clinical outcomes in critically ill patients: results of an international multicenter observation study. Intensive Care Med. 2009; 35(10):1728-37.

24. Japur CC, Monteiro JP, Marchini JS, Garcia RW, Basile-Filho A. Can an adequate energy intake be able to reverse the negative nitrogen balance in mechanically ventilated critically ill patients? J Crit Care. 2010; 25(3):445-50. 
25. Grau T, Bonet A, Rubio M, Mateo D, Farré M, Acosta JA, et al.; Working Group on Nutrition and Metabolism of the Spanish Society of Critical Care. Liver dysfunction associated with artificial nutrition in critically ill patients. Crit Care. 2007; 11(1):R10.

26. Dissanaike S, Shelton M, Warner K, O'Keefe GE. The risk for bloodstream infections is associated with increased parenteral caloric intake in patients receiving parenteral nutrition. Crit Care. 2007; 11(5):R114.

27. Flancbaum L, Choban PS, Sambucco S, Verducci J, Burge JC. Comparison of indirect calorimetry, the Fick method, and prediction equations in estimating the energy requirements of critically ill patients. Am J Clin Nutr. 1999; 69(3):461-6.

28. Basile-Filho A, Martins MA, Bastiston MT, Vinha PP. Gasto energético em pacientes sépticos: correlação entre a calorimetria indireta e as equações preditivas derivadas a partir de dados hemodinâmicos. Rev Bras Ter Intensiva. 2003; 15(3):101-7.

29. Silva SRJ, Waitzberg DL. Gasto energético. In: Waitzberg DL. Nutrição oral, enteral e parenteral na prática clínica. 3. ed. São Paulo: Atheneu; 2000. p. 327-42.

30. Kreymann G. Invited communication: New developments in clinical practice guidelines. S Afr J Clin Nutr. 2010; 23(1):29-32.

31. McClave SA, Martindale RG, Vanek VW, McCarthy M, Roberts P, Taylor B, et al.; A.S.P.E.N. Board of Directors; American College of Critical Care Medicine; Society of Critical Care Medicine. Clinical guidelines for the provision and assessment of nutrition support therapy in the adult critically ill patients: Society of Critical Care Medicine (SCCM) and American Society for Parenteral and Enteral Nutrition (A.S.P.E.N). JPEN Parenter Enteral Nutr. 2009; 33(3):277-316.

32. McCardle WD, Katch FI, Katch VL. Medida do consumo energético em humano. In: McCardle WD, Katch FI, Katch VL, editors. Fisiologia do exercício. Energia, nutrição e desempenho humano. 3. ed. Rio de Janeiro: Guanabara-Koogan; 1991. p. 94-101.

33. Diener JRC. Calorimetria indireta. Rev Ass Med Bras. 1997; 43(3):245-53

34. Daly JM, Heymsfield SB, Head CA, Harvey LP, Nixon DW, Katzeff H, et al. Human energy requeriments: overestimation by widely used prediction equations. Am J Clin Nutr. 1985; 42(6):1170-4.

35. Manual de operações TEEM 100. Porto Alegre: Inbraport - Inbramed Ltda.; s.d. 52 p. p. 43.

36. .Schoeller DA, Ravussin E, Schutz Y, Acheson KJ, Baertschi P, Jéquier F. Energy expenditure by doubly labeled water: validation in humans and proposed calculation. Am J Physiol. 1986; 250(5 Pt 2):R823-30.

37. Nagy KA. Introduction. In: Prentice AM, editor. The doubly labelled water method for measuring energy expenditure. Technical recommendations for use in humans. Vienna: International Dietary Energy Consultancy Group; 1990. p. 1-16.

38. Coward WA, Prentice AM, Murgatroyd PR, Davies HL, Cole TJ, Sawyer M, et al. Measurements of $\mathrm{CO} 2$ and water production rates in man using $2 \mathrm{H} 18 \mathrm{O}$; comparisons between calorimeter and isotopes values. In: Van Es AJH. A concerned action project on nutrition in the European Community. Wageningen: Agricultural University; 1984.

39. Schoeller DA, Webb P. Five-day comparison of the doubly labeled water method with respiratory gas exchange. Am J Clin Nutr. 1984; 40(1):153-8.

40. Scagliusi FB, Lancha Júnior AH. Estudo do gasto energético por meio da água duplamente marcada: fundamentos, utilização e aplicações. Rev Nutr. 2005; 18(4):541-51.

41. Alves VG, da Rocha EE, Gonzalez MC, da Fonseca RB, Silva MH, Chiesa CA. Assessment of resting energy expenditure of obese patients: comparison of indirect calorimetry with formulae. Clin Nutr. 2009; 28(3):229-304.

42. Frankenfield DC, Ashcraft CM. Estimating energy needs in nutrition support patients. JPEN J Parenter Enteral Nutr. 2011; 35(5):563-70.

43. McClave SA, Snider HL. Use of indirect calorimetry in clinical nutrition. Nutr Clin Pract. 1992; 7(5):207-21.

44. Weir JB. New methods for calculating metabolic rate with special reference to protein metabolism. J Physiol. 1949; 109(1-2):1-9.

45. Frayn KN. Calculation of substrate oxidation rates in vivo from gaseous exchange. J Appl Physiol Respir Environ Exerc Physiol. 1983; 55(2):628-34.

46. Simonsen DC, DeFronzo R. Indirect calorimetry: methodological and interpretative problems. Am J Physiol. 1990; 258(3 Pt 1):E399-412.

47. Suen VMM, Da Silva GA, Marchini JS. Determinação do metabolismo energético no homem. Medicina (Ribeirão Preto). 1998; 31(1):13-21.

48. Harris JA, Benedict FG. Standard basal metabolism constants for physiologist and clinicians. In: A biometric study of basal metabolism in man. Philadelphia: JB Lippincott Co.; 1919. p. 223-50.
49. Bartlett RH, Dechert RE, Mault JR, Ferguson SK, Kaiser AM, Erlandson EE. Measurement of metabolism in multiple organ failure. Surgery. 1982; 92(4):771-9.

50. Nixon DW, Kutner M, Heymsfield S, Foltz AT, Carty C, Seitz S, et al. Resting energy expenditure in lung and colon cancer. Metabolism. 1988; 37(11):1059-64.

51. McClave SA, McClain CJ, Snider HL. Should indirect calorimetry be used as part of nutritional assessment? J Clin Gastroenterol. 2001; 33(1):14-9.

52. Wooley JA, Sax HC. Indirect calorimetry: applications to practice. Nutr Clin Pract. 2003; 18(5):434-9.

53. Mullen JL. Indirect calorimetry in critical care. Proc Nutr Soc. 1991; 50(2):239-44.

54. Matarese LE. Indirect calorimetry: technical aspects. J Am Diet Assoc. 1997; 97(10 Suppl 2):S154-60.

55. McClave SA, Spain DA, Skolnick JL, Lowen CC, Kieber MJ, Wickerham PS, et al. Is achievement of steady state optimizes results when performing indirect calorimetry. JPEN J Parenter Enteral Nutr. 2003; 27(1):16-20.

56. Barco KT, Smith RA, Peerless JR, Plaisier BR, Chima CS. Energy expenditure assessment and validation after acute spinal cord injury. Nutr Clin Pract. 2002; 17(5):309-13.

57. Feurer ID, Crosby LO, Mullen JL. Measured and predicted resting energy expenditure in clinically stable patients. Clin Nutr. 1984; 3(1):27-34.

58. Santos LJ, Balbinotti L, Marques AC, Alscher S, Vieira SRR. Gasto energético em ventilação mecânica: existe concordância entre a equação de Ireton-Jones e a calorimetria indireta?. Rev Bras Ter Intensiva. 2009; 21(2):129-34.

59. Mifflin MD, St Jeor ST, Hill LA, Scott BJ, Daugherty SA, Koh YO. A new predictive equation for resting energy expenditure in healthy individuals. Am J Clin Nutr. 1990; 51(2):241-7.

60. Ireton-Jones CS, Turner Jr WW, Liepa GV, Baxter CR. Equations for estimation of energy expenditures in patients with burns with special reference to ventilatory status. J Burn Care Rehabil. 1992; 13(3):330-3.

61. Frankenfield D, Smith JS, Cooney RN. Validation of 2 approaches to predicting resting metabolic rate in critically ill patients. JPEN J Parenter Enteral Nutr. 2004; 28(4):259-64.

62. Hoffer LJ. Protein and energy provision in critical illness. Am J Clin Nutr. 2003; 78(5):906-11.

63. Compher C, Cato R, Bader J, Kinosian BP. Harris-Benedict equations do not adequately predict energy requirements in elderly hospitalized African Americans. J Natl Med Assoc. 2004; 96(2):209-14

64. Reeves MM, Capra S. Variation in the application of acutely ill adult patients: a survey of practice. Eur J Clin Nutr. 2003; 57(12):1530-5.

65. Boullata J, Willians J, Cottrell F, Hudson L, Compher C. Accurate determination of energy needs in hospitalized patients. J Am Diet Assoc. 2007; 107(3):393-401.

66. Cheng CH, Chen CH, Wong Y, Lee BJ, Kan MN, Huang YC. Measured versus estimated energy expenditure in mechanically ventilated critically ill patients. Clin Nutr. 2002; 21(2):165-72.

67. Gottschlich MM, DeLegge MH, Guenter P; American Society for Parenteral and Enteral Nutrition. The A.S.P.E.N. nutrition support care curriculum: a case-based approach - The adult patient. Silver Spring: American Society for Parenteral and Enteral Nutrition; 2007.

68. Academy of Nutrition and Dietetics. Evidence analysis library. Estimating RMR with prediction equations: what does de evidence tell us? [cited 2015 May 12]. Available from: http://andevidencelibrary.com/topic.cfm?cat $=2694$.

69. Frankenfield DC, Ashcraft CM, Galvan DA. Longitudinal prediction of metabolic rate in critically ill patients. JPEN J Parenter Enteral Nutr. 2012; 36(6):700-12.

70. Frankenfield DC, Coleman A, Alam S, Cooney RN. Analysis of estimation methods for resting metabolic rate in critically ill adults. JPEN J Parenter Enteral Nutr. 2009; 33(1):27-36

71. Fiaccadori E, Lombardi M, Leonardi S, Cremaschi E. Prevalence and clinical outcome associated with preexisting malnutrition in acute renal failure: a prospective cohort study. J Am Soc Nephrol. 1999; 10(3):581-93.

72. Gervasio JM, Garmon WP, Holowatyi M R. Nutrition support in acute kidney injury. Nutr Clin Pract.2011; 26(4):374-81.

73. Cano N, Aparicio M, Brunori G, Carrero JJ, Cianciaruso B, Fiaccadori E, et al.; ESPEN. ESPEN guidelines on parenteral nutrition: adult renal failure. Clin Nutr. 2009; 28(4):401-14

74. López Martínez J, Sánchez-Izquierdo Riera JA, Jiménez Jiménez FJ; Metabolism and Nutrition Working Group of the Spanish Society of Intensive Care Medicine and Coronary units. Guidelines for specialized nutritional and metabolic support in the critically-ill patient: update. Consensus SEMICYUC-SENPE: acute renal failure. Nutr Hosp. 2011; 26 Suppl 2:21-6. 
75. Frithiof R. Sepsis-induced acute kidney injury - is there a lack of energy? Intensive Care Med. 2012; 38(5):735-7.

76. Maursetter L, Kight CE, Mennig J, Hofmann RM. Review of the mechanism and nutrition recommendations for patients undergoing continuous renal replacement therapy. Nutr Clin Pract. 2011; 26(4):382-90.

77. Schneeweiss B, Graninger W, Stockenhuber F, Druml W, Ferenci P, Eichinger S; et al. Energy metabolism in acute and chronic renal failure. Am J Clin Nutr. 1990; 52(4):596-601.

78. Monteon FJ, Laidlaw SA, Shaib JK, Kopple JD. Energy expenditure in patients with chronic renal failure. Kidney Int. 1986; 30(5):741-7.

79. Ikizler TA, Wingard RL, Sun M, Harvell J, Parker RA, Hakim RM. Increased energy expenditure in hemodialysis patients. J Am Soc Nephrol. 1996; $7(12): 2646-53$.

80. Avesani CM, Draibe SA, Kamimura MA, Dalboni MA, Colugnati FA, Cuppari L. Decreased resting energy expenditure in non-dialysed chronic kidney disease patients. Nephrol Dial Transplant. 2004; 19(12):3091-7.

81. O'Sullivan AJ, Lawson JA, Chan M, Kelly JJ. Body composition and energy metabolism in chronic renal insufficiency. Am J Kidney Dis. 2002; 39(2):369-75.
82. Bazanelli AP, Kamimura MA, Silva CB, Avesani CM, Lopes MG, Manfredi $\mathrm{SR}$, et al. Resting energy expenditure in peritoneal dialysis patients. Perit Dial Int. 2006; 26(6):697-704.

83. Avesani CM, Draibe SA, Kamimura MA, Colugnati FAB, Cuppari L. Resting energy expenditure of chronic kidney disease patients: influence of renal function and subclinical inflammation. Am J Kidney Dis. 2004; 44(6):1008-16

84. Avesani CM, Cuppari L, Silva AC, Sigulem DM, Cendoroglo M, Sesso R, et al. Resting energy expenditure in pre-dialysis diabetic patients. Nephrol Dial Transplant. 2001; 16(3):556-65

85. Kamimura MA, Draibe SA, Dalboni MA, Cendoroglo M, Avesani CM, Manfredi SR, et al. Serum and cellular interleukin- 6 in haemodialysis patients: relationship with energy expenditure. Nephrol Dial Transplant. 2007; 22(3):839-44.

86. Casaer M, Mesotten D, Schetz M. Bench-to-bedside review: metabolism and nutrition. Crit Care. 2008; 12(4):222-32

87. Brown R, Compher C; ASPEN Board of Directors. A.S.P.E.N. clinical guidelines: nutrition support in adult acute and chronic renal failure. JPEN J Parenter Ent Nutr. 2010; 34(4):366-77. 